\title{
Primary second molar relations in preschool-aged children
}

\author{
Rafinus Arifin*, Taufiqi Hidayatullah**, Sholeha Rahayu* \\ *Department of Orthodontics Faculty of Dentistry Syiah Kuala University, Indonesia \\ **Department of Pedodontics Faculty of Dentistry Syiah Kuala University, Indonesia
}

\begin{abstract}
Introduction: The primary second molar relation is also called the terminal plane, which is the relation between the distal surface of the maxillary and mandibular second primary molars in a centric occlusion position. One of the most important characteristics of the ideal occlusion development on the primary dentition is if the primary second molar relation classified as the flush terminal plane. This relation plays a significant role in determining the relation in permanent molar because the eruption of the first permanent molars are guided by the distal surface of the maxillary and mandibular second primary molars. The purpose of this study was to found out the clinical description of the primary second molar relation among the preschool-aged children in four kindergartens in Banda Aceh. Methods: This study was a descriptive study with cross-sectional study approach. The subject selection method was performed with a purposive sampling method involving as much as 37 subjects, which were students of State Kindergarten of Pembina 1, State Kindergarten 2, State Kindergarten 3, and State Kindergarten of Adidarma 4, Banda Aceh. The examination was performed by using the intraoral mirror when the teeth were in the centric occlusion position. Decisions regarding the primary second molar relation were made by the bilateral occlusion (left and right). Results: The flush terminal plane was found in $45.9 \%$ of all respondents, the mesial step was $54.1 \%$, and the distal step was $0.0 \%$. Conclusion: The primary second molar relation among preschool-aged children generally had the mesial step.
\end{abstract}

Keywords: Distal step, flush terminal plane, mesial step, preschool aged children, primary second molar relation.

P-ISSN 1979-0201, e-ISSN 2549-6212 Available from:http://jurnal.unpad.ac.id/pjd/article/view/16113

DOI:10.24198/pjd.vol30no1.16113

Submission: Dec 2017 Publishing: Mar 2018

\section{INTRODUCTION}

The primary teeth are the first to erupt in the oral cavity, then it will be lost and replaced by permanent teeth. ${ }^{1}$ The period of the deciduous tooth begins with a mandibular central incisor at the age of 6 months and ends with the eruption of permanent first molars by age $6 .^{2,3}$ The deciduous tooth has a special function that is not possessed by permanent teeth, one of which is to guide the eruption of a permanent tooth in place, so as to maintain the growth of the jaw arch. $^{4}$ 
One of the most common problems of the deciduous period is determining the occlusions. ${ }^{5}$ Occlusion plays an important role in the mastication, speech and aesthetic systems. ${ }^{6}$ The occlusion of the deciduous teeth has another important role, which can predict permanent dental occlusion. ${ }^{7}$ Early dentin inclusion is influenced by several factors, namely the loss of tooth structure that can affect mesiodistal and occluso gingival space, have physical or mental disabilities and developmental defects, the presence of dental anomalies, and have bad habits. ${ }^{5,8-11}$

The development of the occlusion of the deciduous tooth begins to form at the age of 3 years because at that age the primary teeth have perfectly erupted. ${ }^{11}$ The age of 3 years is included in preschool age. Preschool age is the transition time between infancy and schoolchildren, aged 3-6 years. ${ }^{12}$ Children of that age prefer sweet foods rather than healthy foods such as vegetables and in maintaining healthy teeth and mouth, children still often forget to brush their teeth. ${ }^{11,13}$ Teeth of children at these ages are more susceptible to caries. Caries at preschool age is the leading cause of premature loss of the tooth. ${ }^{14}$ According to Brodeur et al. in 2006, secondary molar teeth are the teeth most frequently experienced premature loss due to caries. ${ }^{15}$

One of the effects caused by premature loss of the second molar is the difficulty of determining the plane terminal relationship since the relation sees the mesiodistal relationship between the distal surface of the upper and lower jaw molar at the occlusion of centric position. ${ }^{5,7}$ The term plane relations can be categorised into three types, which are flush terminal plane, mesial step, and distal step. ${ }^{16}$ One of the ideal developmental characteristics of the occlusion of the first deciduous teeth is that if the second molar relationship is categorised as flush terminal plane. ${ }^{2,16,17}$ The flush terminals plane occurs when the distal surface the second molars of the upper and lower jaw are in the same vertical plane. ${ }^{16,17,18}$ The condition is normal in the primary teeth because the mesiodistal width of the lower second molar is greater than the maxillary second molar. ${ }^{3,16}$ The relation plays an important role in predicting a permanent molar relationship ${ }^{10}$, because of the first molar eruption permanent depending on the distal surface of the upper and lower second molars of the maxillary.

Research on the relationship of second eldest molar in children with certain age group has been done in many countries. Research on children of Saudi Arabia aged 3-5 years performed by Baidas in 2010 mentions that the second molar relationship flush terminal plane is the most widely found relation, followed by mesial step relation, and distal step. ${ }^{8}$ It is also supported by research in Indian children aged 4-6 years conducted by Bhayya et al. in 2012 stating that the second molar relationship of the flush terminal plane is the most common relation. ${ }^{19}$

Research on Turkish children aged 3-6 years conducted by Yilmaz et al. in 2006 mentions that the second molar relationship of the flush terminal plane is also the most widely found relation, followed by distal step relation, and mesial step. ${ }^{5}$ Different results are disclosed by Al-Ajwadi in 2009 who researched Baghdad children aged 4-5 years, mentions that the second mesial step molar relationship is the most widely found, followed by flush terminal plane, and distal step. ${ }^{20}$

Kindergarten is the level of early childhood education in the form of formal education. State kindergarten was established and funded by the local government. There are four kindergartens in the city of Banda Aceh, namely State Kindergarten of Pembina 1, State Kindergarten 2, State Kindergarten 3, and State Kindergarten of Adidarma $4 .{ }^{21}$ The above description encourages researchers to conduct research on the image of the second eldest molar relation, because in the country of Indonesia, especially in the city of Banda Aceh this study has never been done. Therefore the researcher is interested in researching the image of the second eldest molar relation in preschool children by taking the subject in four State Kindergarten in Banda Aceh.

\section{METHODS}

The research design used was cross-sectional. Cross-sectional research is an observation performed at one time or a certain period with the characteristics of each subject only observed or checked once in one study. The research was conducted in State Kindergarten of Pembina 1, State Kindergarten 2, State Kindergarten 3, and 
State Kindergarten of Adidarma 4 Banda Aceh in May-June 2016.

The study population was all 345 students in four State Kindergarten of BandaAceh. The subjects of the study were preschool-aged students in four State Kindergarten of Banda Aceh who fulfilled the inclusion criteria. The determination of the subjects was done by non-random sampling (nonprobability) with purposive sampling technique, the subject was not randomly selected but chose the subject among the population according to the inclusion and exclusion criteria. The inclusion criteria of the study subjects were, preschool age students in four State Kindergarten of Banda Aceh, with parents were willing to sign informed consent, and the first teeth were still complete; none of the missing primary teeth. ${ }^{5,10,22,23}$ Criteria exclusion of the study is a subject of research that is not willing to follow the research and if the subject has mesial step occlusion on one side and the other side has a distal occlusion step.

Tools and materials used are intraoral scents, gloves, mask, cotton, flashlight, antiseptic solution (Dettol ${ }^{\circledR}$ ) and alcohol, Nierbeken, Tissue, Stationery, Chairs, Informed consent, Questionnaire to select the subject, and examination form of the second primary molar.

Examination of second primary molar relation done a day after completion of the subject selection process of research done. The subject of the research at the time of examination accompanied by the parent/guardian of the subject. Subsequently, the subject of the study was examined in a chair with an upright sitting position, with the head halfway up. The oral examination is performed under a light source. The second primary molar relation is examined in centric inclusion position by using an intraoral mirror, then photographs are taken.

The second molar relation of the upper and lower jaw (terminal plane) can be classified into three, namely the flush terminal plane, the distal step, and the mesial step. ${ }^{5}$ The decision of the second primary molar relationship is made based on bilateral occlusion (left and right), if one the occlusion side ends with the distal or mesial step and the other ends with the flush terminal plane, it will be recorded as the flush terminal plane. If one side ends with mesial step and the other side has a distal occlusion step, it is removed from the assessment. ${ }^{5,8}$ The results of the clinical examination are recorded on the examination form.

Data collected through a clinical examination conducted on the subject of research then recorded and processed using univariate data analysis to describe the variables measured by looking at the percentage of the number of subjects. Data is presented in the form of frequency distribution table.

\section{RESULTS}

This study was conducted on students who meet the inclusion criteria at State Kindergarten of Pembina 1, State Kindergarten 2, State Kindergarten 3, and State Kindergarten of Adidarma 4, Banda Aceh, on May 10-June 10, 2016. The number of research subjects meeting the inclusion criteria was 37 people from a population of 345 people. Subjects that did not meet the majority inclusion criteria were due to extensive and proximal caries that affected mesiodistal dimensions and occlusogingival primary teeth. The second molar and the incisor are the most carious teeth.

Table 1 menu of subject demographic data included in the study. There were 37 subjects State Kindergarten of Pembina 1, State Kindergarten 2, State Kindergarten 3, and State Kindergarten of Adidarma 4 which examined the second eldest molar relation consisting of 19 people (51.4\%) male and 18 people $(48.6 \%)$ female.

Table 1. Preschool aged children based on gender

\begin{tabular}{|c|c|c|c|c|c|}
\hline \multirow[b]{2}{*}{ Gender } & \multicolumn{4}{|c|}{ School } & \multirow[b]{2}{*}{ Total } \\
\hline & $\begin{array}{c}\text { State Kindergarten of } \\
\text { Pembina } 1\end{array}$ & $\begin{array}{c}\text { State Kindergarten } \\
2\end{array}$ & $\begin{array}{c}\text { State Kindergarten } \\
3\end{array}$ & $\begin{array}{c}\text { State Kindergarten of } \\
\text { Adidarma } 4\end{array}$ & \\
\hline Male & $4(21.1 \%)$ & $6(31.6 \%)$ & $5(26.3 \%)$ & $4(21.1 \%)$ & 19 (100\%) \\
\hline Female & $8(44.4 \%)$ & $4(22.2 \%)$ & $5(27.8 \%)$ & 1 (5.6\%) & $18(100 \%)$ \\
\hline Total & $12(32.4 \%)$ & $10(27.0 \%)$ & $10(27.0 \%)$ & $5(13.5 \%)$ & 37 (100\%) \\
\hline
\end{tabular}


Table 2. Primary second molar relations description based on bilateral occlusion on the examined pre-school aged children

\begin{tabular}{cccc}
\hline \multirow{2}{*}{ Terminal Plane } & \multicolumn{2}{c}{ Subject number $(\mathrm{N})$} & Percentage \\
\cline { 2 - 3 } & Male & Female & $(\%)$ \\
\hline Flush terminal plane & 10 & 7 & 45.9 \\
Mesial step & 9 & 11 & 54.1 \\
Distal step & 0 & 0 & 0.0 \\
\hline
\end{tabular}

Table 2 presented the second molar second relation data if one side ends with a mesial step and the other ends with the distal step of the study subjects, the result was found that $54.1 \%$ of the study subjects had second mesial step molar secondary, while $45.9 \%$ subjects has the second molar second flush of the terminal plane, and no second distal mother molar relation was found.

\section{DISCUSSION}

Occlusion plays an important role in the mastication, speech and aesthetic systems. ${ }^{6}$ The occlusion of primary teeth has another important role in predicting permanent dental occlusion. The occlusion of the deciduous tooth can be affected by several factors, namely the loss of tooth structure which can affect the mesiodistal and occluso-gingival dimensions, have physical or mental disabilities and developmental defects, the presence of dental anomalies, and have bad habits., ${ }^{2,511-12}$ One of the most important characteristics of the development of dental occlusion can be seen from their second molar relationship. The second primary molar's relationship is considered the most important because it can predict a permanent molar relationship. This is because the permanent first molar eruption depends on the distal surface of the upper and lower middle molars.

The second elderly molar relation is also called the terminal plane, the mesiodistal relation between the distal surface of the upper and lower jaw molars of the upper jaw which is assessed when the primary tooth is in the centric occlusion position. $5,7-10,22,24$ The relation can be classified into three types according to Baume, which are flush terminal plane, mesial step, and distal step. ${ }^{16}$ This study focuses on the examination of the second primary molar relationship performed when the tooth is in centric inclusion position by using an intraoral mirror. Decisions about the second primary molar relationships are made based on bilateral occlusion (left and right). If one side ends with a distal or mesial step and the other ends with a flush terminal plane, it is recorded as a flush terminal plane. If one side ends with a mesial step and the other ends with the distal step, it is removed from the rating. ${ }^{5,8}$

The study of Baidas and Vegesna et al., showed that the number of subjects examined for the second primary molar relation was more of the female sex. ${ }^{8,23}$ According to these studies no mention of the underlying causes of the different number of male and female sex subjects examination of the second primary molar relation. In general, the subjects were viewed from the inclusion and exclusion criteria. Many subjects were excluded from the study because they had extensive caries and proximal caries that affected mesiodistal dimensions and occluso-gingival primary teeth. The caries were caries belonging to the caries classification of site 1 -size 4 and site 2-size 4 according to G.J. Mount. ${ }^{26}$ According to research conducted by Bhardwaj in 2014, caries prevalence is more prevalent in girls than in men. ${ }^{27}$ Ferraro and Vieira mentioned that there had been many studies suggesting that caries rates in women are higher than in men. This is because the lower salivary flow rate in women thus causing high caries risk and hormonal fluctuations that occur in women also causes the composition and salivary flow rate to decrease. ${ }^{28}$

The conclusion of the description of the second primary molar relation in this study was presented in Table 2. Table 2 mentioned that the mesial step's second molar relation is the most commonly found on the subjects in State Kindergarten of Pembina 1, State Kindergarten 2, State Kindergarten 3, and State Kindergarten of Adidarma 4 . There are $54.1 \%$ of the total subjects who have a picture of the mesial step's second molar relation, and the rest have the image of the second molar of the flush terminal plane that is as much as $45.9 \%$. This is in line with Al-Ajwadi's study conducted in 2009 which stated that the mesial step's second molar relation is the most commonly found in children aged 4-5 years in Baghdad, followed by flush terminal relations, and distal step. ${ }^{20}$ Also supported by studies in children 
aged 3-5 years in India conducted by Bahadure et al. in 2012 which also stated that the mesial step's second molar relationship is the most widely found. ${ }^{7}$ Different research results stated by Baidas in 2010 in children aged 3-5 years in Saudi Arabia, mentions that the second molar relationship flush terminal plane is the most widely found relation, followed by mesial step relation, and distal step. ${ }^{8}$ Research on children aged 3-6 years old in Turkey conducted by Yilmaz et al. in 2006 mentions that the second molar relationship of the flush terminal plane is also the most commonly found relation, followed by the distal step relation, and mesial step. ${ }^{5}$ It was also consistent with the study of Talebi et al. in 2012 in children aged 3-5 years in Iran. ${ }^{25}$

The second primary molar relation found in the subject of either the mesial step or the flush terminal plane can predict its permanent molar relationship. ${ }^{10}$ The mesial step relation may develop into the first permanent first molar of class I. Some cases become permanent third class molar if the growth of the mandible the forward direction lasts long. ${ }^{2,17}$ The flush terminals of the plane can develop into a permanent molar of class I. ${ }^{2}$ Some cases develop into second-class permanent molar relations if the forward mandibular growth is imperfect. ${ }^{17}$ This is consistent with the longitudinal study of Tsourakis and Johnston in 2014 who saw the image of the second primary molar relation until it developed into a permanent molar relationship. The study states that of the 6 subjects with the mesial step's second molar relation, 5 of them evolved into the first class permanent molar relation, and the rest developed into an end-to-end permanent molar relationship. Likewise, with 24 subjects with the second molar of the flush terminal plane, 13 developed into a permanent molar of class I, 5 of the subjects being class II permanent molar and the remainder being an end-to-end permanent molar. ${ }^{29}$ However, it does not guarantee that later the second primary molar relations will always evolve as already mentioned. Several other factors can cause the change in the occlusion of primary teeth resulting in the second elderly molar relation also changed, one of which is bad habits. ${ }^{28}$ Bad habits found at preschool age, such as sucking on the thumb, finger/lip bite, tongue thrusting, bruxism, breathing through the mouth, and biting the nails. ${ }^{30}$
This study cannot look only at the second primary molar relation which has an important role in predicting a permanent molar relationship. The weakness of this study is that the research subjects are small, so it can not represent the image of the second primary molar relation in preschool children in Banda Aceh.

\section{CONCLUSION}

The primary second molar relation among preschool-aged children generally had the mesial step with no distal step was found in all subjects. This research had a simple scope. Further research regarding the second molar relation can be conducted. Therefore, this study might become a reference to analyse the relationship between the second primary molar relation with gender, age, bad habits, and age when first tooth eruption and further research on a larger scope.

\section{REFERENCES}

1. Kumar PS. Dental anatomy and tooth morphology. New Delhi: Jaypee Brothers Medical Publishers Ltd.; 2004. p. 1.

2. Singh G. Textbook of orthodontics. $2^{\text {nd }}$ ed. New Delhi: Jaypee Brothers Medical Publishers (P) Ltd.; 2007. p. 38-40,43-5.

3. Manjunatha BS. Textbook of dental anatomy and oral physiology including occlusion and forensic odontology. $1^{\text {st }}$ ed. New Delhi: Jaypee Brothers Medical Publishers Ltd.; 2013. p. 33-4.

4. Mamonto EDI, Wowor VNS, Gunawan P. Gambaran kehilangan gigi sulung pada siswa Madrasah Ibtidaiyah Darul Istiqamah Bailang. J Ked Komun Trop. 2014 May;2(2):90-4.

5. Yilmaz Y, Gurbuz T, Simsek S, Dalmis A. Primary canine and molar relationships in centric occlusion in three to six year-old Turkish children: A cross-sectional study. J Contemp Dent Pract. 2006 Jul;7(3):1-7.

6. Turp JC, Greene CS, Strub JR. Review article dental occlusion: A critical reflection on past, present, and future concepts. J Oral Rehabil. 2008 Jun;35(6):446-53. DOI: 10.1111/j.0305182X.2007.01820.x

7. Bahadure RN, Thosar N, Gaikwad R. Occlusal traits of deciduous dentition of preschool children of Indian children. Contemp Clin Dent 
2012 Oct-Dec;3(4):443-7. DOI: $10.4103 / 0976-$ 237X.107437

8. Baidas LF. Occlusion characteristics of primary dentition by age in a sample of Saudi preschool children. Pak Oral Dent J 2010 Dec;30(2):42531.

9. Hegde S, Panwar S, Bolar DR, Sanghavi $M B$. Characteristics of occlusion in primary dentition of preschool children of Udaipur, India. Eur J Dent 2012 Jan;6(1):51-5.

10. Sriram CH, Priya VK, Sivakumar N, Reddy KRM, Babu PJ, Reddy P. Occlusion of primary dentition in preschool children of Chennai and Hyderabad: A comparative study. Contemp Clin Dent 2012 Jan-Mar;3(1):31-7.

11. Dean J, McDonald R, Avery D. Dentistry for the child and adolescent. $9^{\text {th }}$ ed. St. Louis: MosbyElsevier; 2010. p. 41-2,150-1,219,518.

12. Gill DS, Naini FB. Orthodontics: Principles and practice. Hoboken: Wiley-Blackwell; 2011. p. 17.

13. Scaglioni S, Arrizza C, Vecchi F, Tedeschi S. Determinants of children's eating behavior. Am J Clin Nutr 2011 Dec;94(6 Suppl):2006S2011S. DOI: 10.3945/ajen.110.001685

14. Alim S, Fatimah. Pola makan dan kebiasaan menggosok gigi dengan timbulnya karies gigi pada anak. J Pediatr Nurs. 2014;1(3):131-6.

15. Brodeur JM, Galarneau C. The high incidence of early childhood caries in kindergarten-age children. JODQ. 2006 Apr;Suppl:3-5.

1. Phulari RGS. Textbook of dental anatomy, physiology and occlusion. New Delhi: Jaypee Brothers Medical Publishers Ltd.; 2013. p. 307,309-10.

16. Phulari BS. Orthodontics principles and practice. $1^{\text {st }}$ ed. New Delhi: Jaypee Brothers Medical Publishers Ltd.; 2011. p. 66-70.

17. Rao A. Principles and practice of pedodontics. $3^{\text {rd }}$ ed. New Delhi: Jaypee Brothers Medical Publishers Ltd.; 2012. p. 96-7.

18. Bhayya DP, Shyagali TR, Dixit UB, Shivaprakash. Original article study of occlusal characteristics of primary dentition and the prevalence of maloclusion in 4 to 6 years old children in India. Dent Res J (Isfahan). 2012 Sep-Oct;9(5):619-23.
19. Al-Ajwadi SAM. Malocclusion of primary dentition among kindergarten children in Zayona Part of Baghdad City. J Bagh Coll Dent 2009;21(1):104-6.

20. BPM Kota Banda Aceh. Data Sekolah TK Kota Banda Aceh. Banda Aceh: BPM Kota Banda Aceh; 2014.

21. Bhat SS, Rao HTA, Hegde KS, Kumar BSK. Characteristics of primary dentition occlusion in preschool children: An epidemiological study. Int J Clin Pediatr Dent 2012 May-Aug;5(2):93-7. DOI: $10.5005 /$ jp-journals-10005-1143

22. Vegesna M, Chandrasekhar R, Chandrappa V. Occlusal characteristics and spacing in primary dentition: A gender comparative cross-sectional study. Int Schol Res Notices 2014:2014:1-7. DOI: $10.1155 / 2014 / 512680$

23. Iyyer BS. Orthodontics: The art and science. $3^{\text {rd }}$ ed. New Delhi: Arya (Medi) Publishing House; 2004. p. 41-2,55,70,82,443-4.

24. Talebi M, Ajami B, Sahebalam R. Evaluation of the occlusion and arch dimensions in the primary dentition of an Iranian population. JDMT 2013 Mar;2(1):11-6.

25. Mount GJ, Hume WR, Ngo HC, Wolff MS. Preservation and restoration of tooth structure. $2^{\text {nd }}$ ed. Queensland: Knowledge Books and Software; 2005. p. 245-6.

26. Bhardwaj VK. Dental caries prevalence in individual tooth in primary and permanent dentition among 6-12 year old school children in Shimla, Himachal Pradesh. Int J Health Allied Sci. 2014 May;3(2):125-8. DOI: 10.4103/2278344X.132700

27. Garde JB, Suryavanshi RK, Jawale BA, Deshmukh V, Dadhe DP, Suryavanshi MK. An epidemiological study to know the prevalence of deleterious oral habits among 6 to 12 year old children. J Int Oral Health. 2014 Feb;6(1):39-43.

28. Tsourakis AK, Johnston LE. Class II malocclusion: The aftermath of a "perfect storm". Seminars in Orthod 2014 Feb;20(1):5973. DOI: $10.1053 /$ j.sodo.2013.12.006

29. Senjaya AA. Kebiasaan buruk yang dapat merubah bentuk wajah. J Skala Husada 2012 Apr;9(1):22-7. 